\title{
Comparative Studies on the Amino Acid and Protein Content of Broiler and Layer Chicken Feathers
}

\author{
S. V. Bharathi ${ }^{1}$ and Indu V. Raj $^{2^{*}}$ \\ ${ }^{1}$ Department of Veterinary Anatomy and Histology, College of Veterinary and Animal \\ Sciences, Mannuthy Thrissur-680 651, Kerala, India \\ ${ }^{2}$ College of Veterinary and Animal Sciences, Pookode, Wayanad, Kerala, India \\ *Corresponding author
}

\section{A B S T R A C T}

\section{Keywords}

Broiler chicken, Layer chicken feather, amino acid and protein content

\section{Article Info}

Accepted:

15 June 2021

Available Online:

10 July 2021
Studies were undertaken on the feather of broiler chicken of six to eight weeks of age and culled White Leghorn birds above 64 weeks of age, slaughtered at Meat Technology Unit, Mannuthy. The feather samples were collected from a total of 24 birds comprising of six males and females from the broiler and layer groups. In the present study the amino acid composition of both broiler and layer chicken feather keratin consisted of both hydrophilic and hydrophobic amino acids with high serine content (12.40 per cent), followed by glutamine ( 9.65 per cent), cystine ( 7.68 per cent), glycine (6.85 per cent), leucine (5.62 per cent), aspartic acid (5.55 per cent), proline (4.52 per cent) and valine (4.21 per cent). It was seen that the feather fibre consisted of more hydrophobic amino acids than hygroscopic in both broiler and layer birds. The FTIR-ATR (Fourier Transform Infrared Spectroscopy- Attenuated Total Reflectance) spectrum of feather of broiler and layer chicken feather showed characteristic bands of proteins, related to the keratinous material. The amide I, II and III band were shown in between the range of $1700-1600 \mathrm{~cm}^{-1}$ with a peak at $1631 \mathrm{~cm}^{-}$ ${ }^{1} ; 1600-1500 \mathrm{~cm}^{-1}$ with a peak at $1540 \mathrm{~cm}^{-1}$ and $1330-1200 \mathrm{~cm}^{-1}$ with a peak at 1232 $\mathrm{cm}^{-1}$ respectively. In all samples the peak intensity of amide II bands was lesser than the amide I peak. There were no major differences in the chemical structures between broiler and layer samples. The results of the present study confirmed that both broiler and White Leghorn chicken feathers could be beneficiated as a good source of protein.

\section{Introduction}

The increased use of chicken meat has led to the generation of millions of tonnes of feather waste. Hence it is necessary to find better ways for effective and profitable utilization of chicken feather, which would definitely increase its worth. Feathers are made of keratin, the tough, tightly wound protein fiber, which gives it numerous properties. Hence the present study was conducted to assess the amino acid and protein content of chicken feather so that new ways can be developed to process poultry feathers into valuable 
products, replacing wood pulp and other expensive fibers.

\section{Materials and Methods}

Studies were undertaken on the feather of broiler chicken of six to eight weeks of age and culled White Leghorn birds above 64 weeks of age, slaughtered at Meat Technology Unit, Mannuthy. The feather samples were collected from a total of 24 birds comprising of six males and females from the broiler and layer groups. Immediately following exsanguination, primary and secondary remiges were collected from the 12 wing feathers of each bird to study the physical properties. To clear out the foreign materials clung to the feathers, they were first washed with five per cent non-ionic liquid soap solution followed by rinsing and exposed to natural light until completely dried. The feathers were sterilized with $95 \%$ ethanol at $21^{\circ} \mathrm{C}$ for $30 \mathrm{~min}$ (Fan, 2008). They were then rinsed with water and dried. The sterilized feathers were then processed to get fibres. The feathers were dried and conditioned at a relative of humidity $(\mathrm{RH}) 65 \pm 2 \%$ and a temperature of $20 \pm 2{ }^{\circ} \mathrm{C}$. The barbs were separated from the rachis manually by cutting with scissors. The samples of chicken feathers were then tested to assess the amino acid and protein content.

\section{Amino Acid Estimation}

The chicken feather barb samples each $250 \mathrm{~g}$ were weighed accurately in an electronic balance and transferred into labeled glass tubes (BOROSIL). $3 \mathrm{ml}$ of $6 \mathrm{M}$ hydrochloric acid solution was added to the sample in a specified test tubes. All the sealed tubes were kept in a hot air oven at $110^{\circ} \mathrm{C}$ for $24 \mathrm{hrs}$. After completion, the digest was transferred into glass beaker (BOROSIL) and rinsed five times with distilled water. The samples were transferred to $3 \mathrm{ml}$ Eppendorf tubes and the acid in the digest was evaporated to core dry under vacuum Rota-vac evaporator. This was followed by derivatization of free amino acids in the sample with O-phthalaldehyde (OPAthiol) and 9-fluorenyl-methyl chloroformate (FMOC) as precolumn derivatization reagents using C18 column. Finally, derivatized samples, standards and blanks were analyzed with high-performance liquid chromatography (HPLC). The quantitative amino acid composition was determined by calibration with amino acid Standard. The standard amino acids used were glycine, glutamic acid, asparagine, cysteine, threonine, valine, lysine, methionine, hydroxy proline, isoleucine, phenyl alanine, tryptophan, leucine, glycine, serine, alanine, tyrosine, arginine and aspartic acid (Nuutinen, 2017).

\section{Secondary Structures of Proteins}

The spectra of the secondary structures of feather keratin were obtained using an FTIR (Fourier transform infrared system) 2000 (Perkin-Elmer Co.) with diamond ATR (Attenuated Total Reflectance) attachment (Golden Gate Diamond, ATR, Specac) (Endo et al., 2008). Each spectrum contained an average of 6 scans, recorded at a resolution in the range of $4000-400 \mathrm{~cm}^{-1}$ (Tesfaye et al., 2017).

\section{Results and Discussion}

\section{Amino Acid Estimation}

In the present study the amino acid composition of both broiler and layer chicken feather keratin consisted of high serine content (12.40 per cent), followed by glutamine ( 9.65 per cent), cystine (7.68 per cent), glycine (6.85 per cent), leucine (5.62 per cent), aspartic acid (5.55 per cent), proline (4.52 per cent) and valine (4.21 per cent) while the content of histidine, lysine, tyrosine, asparagine, phenylalanine and methionine was the lowest. 
It was seen that the feather fibre consisted of more hydrophobic amino acids and then hygroscopic in broiler and layer birds. These observations are parallel to the reports of Saravanan and Dhurai (2012) and Nuutinen (2017) in chicken. However Arai et al., (1983) and Fraser and Parry (1996), observed that cystine was present in the largest quantity (17.7 per cent weight). These slight variations might be because the amino acid content in the feathers depended on the age, breed, environment and food as noticed by Fisher et al., (1980), Schmidt (1998) and MartinezHernández et al., (2005). In the study of Yin et al., (2013), it was observed that due to breakages during the acid hydrolysis, the content of asparagine, glycine, cystine, serine, threonine and trptophan in the feather samples were inaccurate during amino acid analysis.

Arai et al., (1983) observed that cystine provided thiol groups which interacted to form disulfide bonds and contributed to the hydrophobicity and semi-crystalline nature of feather keratin. Serine contained the hydroxyl $(-\mathrm{OH})$ group and made it hydrophilic. Schmidt and Jayasundera (2004) stated that the hydrophilicity and hydrophobicity of feather was based on its amino acid content. More specifically, it depended on which amino acids were seen on the internal or external surface. Saravanan and Dhurai, (2012) reported that the high content of cystine formed a network of disulphide cross-links between adjacent polypeptides and made the feather keratin stable.

\section{Secondary Structures of Proteins}

The FTIR-ATR (Fourier Transform Infrared Spectroscopy- Attenuated Total Reflectance) spectrum of feather of broiler and layer chicken feather showed characteristic bands of proteins, related to the keratinous material (Fig 1). The amide I band shown in between the range of $1700-1600 \mathrm{~cm}^{-1}$ with a peak at $1631 \mathrm{~cm}^{-1}$ could be assigned to the $\mathrm{C}=\mathrm{O}$ amide I, an $\alpha$-helix conformation (Miyazawa and Blout, 1961 and Senoz and Wool, 2010).

According to Leon (1975) when keratins were hydrolyzed by strong alkali, $\beta$-elimination took place in the first stage and thereafter the peptide chains were cleaved continuously.

In amide II bands were in the range of 1600$1500 \mathrm{~cm}^{-1}$ and the peak seen at $1540 \mathrm{~cm}^{-1}$, was caused by the stretching of $\mathrm{C}-\mathrm{N}$ in keratin and vibrations of the deformation angle of $\mathrm{N}-\mathrm{H}$ of $\beta$-helix (Silverstein et al., 2014). In all samples the peak intensity characteristic of amide II conformation, was lesser than the amide I peak.

In the present study, the amide III region was clearly-defined in the range of 1330-1200 $\mathrm{cm}^{-}$

1 with a peak at $1232 \mathrm{~cm}^{-1}$ due to the vibrations of $\mathrm{C}-\mathrm{N}$ stretching and $\mathrm{N}-\mathrm{H}$ in-plane bending seen in $\alpha$-helix conformation (Martinez-Hernandez and Velasco-Santos, 2012).

The bands from 3,300 to $3,150 \mathrm{~cm}^{-1}$ corresponded to the range of the amide $\mathrm{A}$ and $\mathrm{B}$ bands due to fermi resonance (Kong and $\mathrm{Yu}, 2007)$. The characteristic bands at 2850$2930 \mathrm{~cm}^{-1}$ represented symmetric and asymmetric stretching of aliphatic hydrocarbons (Silverstein et al., 2014; Kim and Hochstrasser, 2009). There were no major differences in the chemical structures between broiler and layer samples. Tesfaye et al., (2017) revealed that due to the presence of proteinous functional group in chicken feather samples they were suitable for use as a raw material in various industries. 
Table.1 Comparison of amino acid content in feather fibres from broiler and White Leghorn chicken

\begin{tabular}{|c|c|c|c|c|}
\hline \multirow[t]{2}{*}{ Sl.No. } & \multirow{2}{*}{$\begin{array}{l}\text { Functional } \\
\text { groups }\end{array}$} & \multirow[t]{2}{*}{ Amino acids } & Broiler chicken & Layer chicken \\
\hline & & & $\%$ contents & $\%$ contents \\
\hline 1 & $\begin{array}{l}\text { Positively } \\
\text { charged }\end{array}$ & Arginine & 4.42 & 4.54 \\
\hline \multirow[t]{2}{*}{2} & \multirow{2}{*}{$\begin{array}{c}\text { Negatively } \\
\text { charged }\end{array}$} & Aspartic acid & 5.55 & 5.47 \\
\hline & & Glutamine & 7.30 & 7.43 \\
\hline \multirow[t]{2}{*}{3} & \multirow[t]{2}{*}{ Hygroscopic } & Serine & 12.40 & 12.27 \\
\hline & & Threonine & 4.34 & 4.55 \\
\hline \multirow[t]{8}{*}{4} & \multirow[t]{8}{*}{ Hydrophobic } & Tyrosine & 1.45 & 1.35 \\
\hline & & Leucine & 5.62 & 5.70 \\
\hline & & Isoleucine & 3.30 & 3.23 \\
\hline & & Valine & 4.21 & 4.25 \\
\hline & & Cystine & 7.68 & 7.57 \\
\hline & & Alanine & 3.54 & 3.52 \\
\hline & & Phenylalanine & 0.85 & 0.93 \\
\hline & & Methionine & 0.32 & 0.27 \\
\hline \multirow[t]{2}{*}{5} & \multirow[t]{2}{*}{ Special } & Proline & 4.52 & 4.67 \\
\hline & & Asparagine & 0.04 & 0.02 \\
\hline \multirow[t]{4}{*}{6} & \multirow[t]{4}{*}{ Others } & Glycine & 6.85 & 6.26 \\
\hline & & Lysine & 1.21 & 1.38 \\
\hline & & Histidine & 0.06 & 0.13 \\
\hline & & Glutamic acid & 9.65 & 9.83 \\
\hline
\end{tabular}

Fig.1

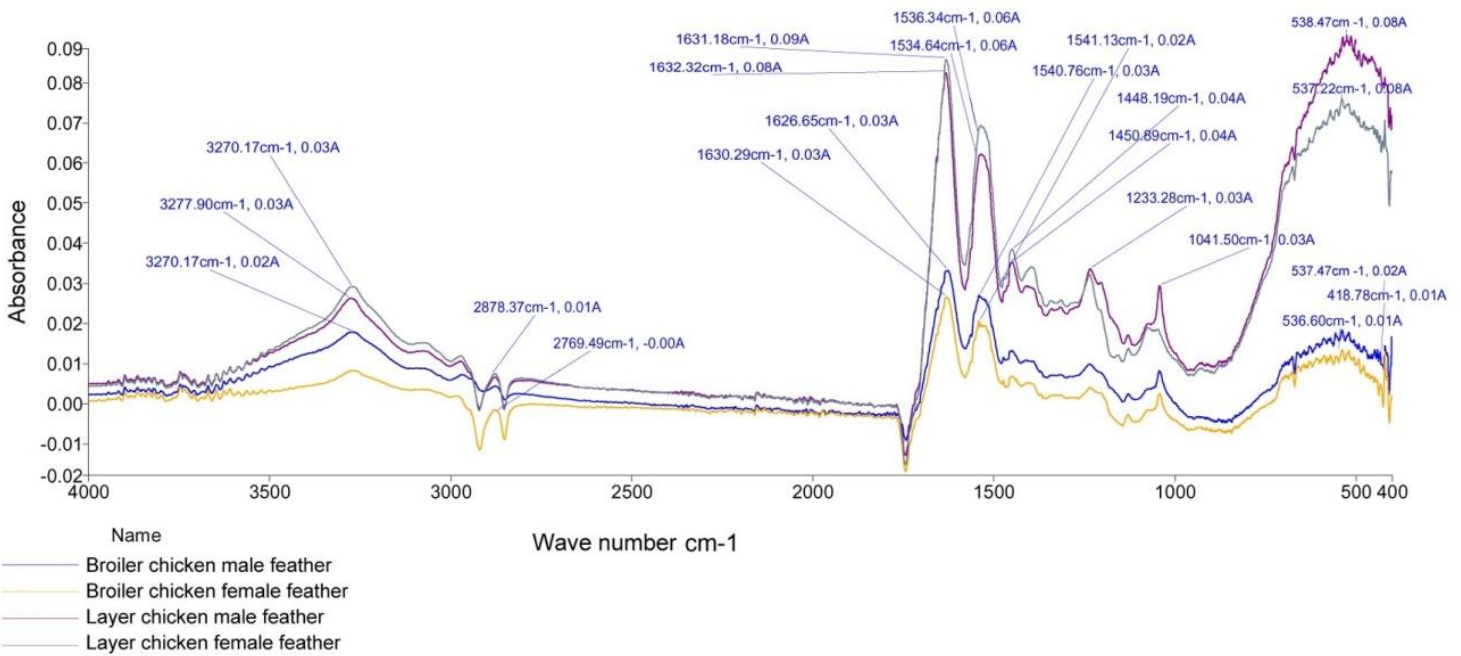

Fig. 1. Comparison of FTIR-ATR spectra in broiler male (BM), broiler female (BF), layer male (LM) and layer female (LF) 
The results of the present study confirmed that both broiler and White Leghorn chicken feathers could be beneficiated as a good source of protein and were suitable for use as a raw material in bioplastics, textile sizing, enzyme production, pharmaceuticals and cosmetics industry. Future research work may be carried out for extraction of valuable materials from poultry feathers, and its conversion into relevant high-value products.

\section{References}

Arai, K. M., Takahashi, R., Yokote, Y. and Akahane, K. 1983. Amino Acid Sequence of Feather Keratin from Fowl. Eur. J. Biochem. 132: 501-507.

Endo, R., Kamei, K., Iida, L. and Kawahara, Y. 2008. Dimensional stability of waterlogged wood treated with hydrolyzed feather keratin. $J$. Archaeological Sci. 35: 1240-1246.

Fisher, M. L., Leeson, S., Morrison, W. D. and Summers, J. D. 1981. Feather growth and feather composition of broiler chickens. Can. J. Anim. Sci. 61: 769773.

Fraser, R. D. B. and Parry, D. A. D. 1996. The molecular structure of reptilian keratin. Int. J. Biol. Macromol. 19: 207-211.

Freddi, G., Innocenti, R., Arai, T., Shiozaki, H. and Tsukada, M. 2003. Physical properties of wool fibres modified with isocyanate compounds. J. Appl. Polym. Sci. 89: 1390-1396.

Jagadeeshgouda, K. B., Reddy, P. R. and Ishwaraprasad, K. 2014. Experimental study of behaviour of poultry feather fibre: a reinforcing material for composites. Int. J. Res. Engng. Technol. 3: 362-366.

Kim, Y. S. and Hochstrasser, R. M. 2009. Applications of 2D IR spectroscopy to peptides, proteins, and hydrogen-bond dynamics. J. Phys. Chem. B. 113: 8231-8251.
Kong, J. and Yu, S. 2007. Fourier transform infrared spectroscopic analysis of protein secondary structures. Acta. Biochimica. et biophysica. Sinica. 39: 549-559.

Leon, J. A. and Tumpson, D. B. 1975. Competition between two species for two complementary or substitutable resources. J. Theor. Biol. 50: 185-201.

Martínez-Hernández, A. L. and C. VelascoSantos, 2012. Keratin: Structure, Properties and Applications. Nova Science Publishers, Mexico. 978p.

Martinez-Hernandez, A. L., Velasco-Santos, C., De Icaza, M. and Castano, V. M. 2005. Microstructural characterisation of keratin fibres from chicken feathers. Int. J. Environ. Pollut. 23: 162-178.

Miyazawa, T. and Blout, E. R. 1961. The infrared spectra of polypeptides in various conformations: amide I and II bands1. J. Am. Chem. Soc. 83: 712719.

Nuutinen, E. 2017. Feather characterization and processing. Master's thesis, Aalto University, Espoo, 76p.

Saravanan, K. and Dhurai, B. 2012. Exploration on the amino acid content and morphological structure in chicken feather fibre. J. Textile Apparel Technol. Mgmt. 7: 1-6

Schmidt, W. F. 1998. Innovative feather utilization strategies. Proceedings of the 1998 National poultry waste management symposium; $19^{\text {th }}$ to $22^{\text {nd }}$ October, 1998, Springdale, Arkansas, Auburn, United States. pp. 276-282.

Schmidt, W. F. and Jayasundera, S. 2004. Natural Fibres, Plastics and Composites. $\quad\left(1^{\text {st }}\right.$ Ed.). Springer, Boston, MA, USA, 370p.

Senoz, E. and Wool, R. P. 2010. Microporous carbon-nitrogen fibres from keratin fibres by pyrolysis. J. Appl. Polym. Sci. 118: 1752-1765.

Silverstein, R. M., Webster, F. X., Kiemle, D. 
J. and Bryce, D. L. 2014. Spectrometric identification of organic compounds. ( $8^{\text {th }}$ Ed.). John Wiley and Sons, USA, 464p.

Tesfaye, T., Sithole, B., Ramjugernath, D. and Chunilall, V. 2017. Valorisation of chicken feathers: Characterisation of physical properties and morphological structure. J. Cleaner Prod. 149: 349365.

Yin, X. C., Li, F. Y., He, Y. F., Wang, Y. and Wang, R. M. 2013. Study on effective extraction of chicken feather keratins and their films for controlling drug release. Biomaterials Sci. 1: 528-536.

\section{How to cite this article:}

Bharathi, S. V. and Indu V. Raj. 2021. Comparative Studies on the Amino Acid and Protein Content of Broiler and Layer Chicken Feathers. Int.J.Curr.Microbiol.App.Sci. 10(07): 446-451. doi: https://doi.org/10.20546/ijcmas.2021.1007.049 